Habib Ali al-Jufri bagi saya bukan cuma da'i, sehebat apa pun beliau. Beliau adalah seorang intelektual Muslim dan pemikir sufi kaliber dunia. Meski tak bisa dipungkiri bahwa beliau besar dan berakar kuat dalam lingkungan tradisi Thariqah 'Alawiyah, pemikiran beliau jauh melampui itu semua. Lebih lagi dalam hal sikap kemanusiaan, Habib Ali adalah teladan dan personifikas sifat welas asih, toleransi dan moderasi ajaran agama Islam. Kita semua berterima kasih atas upaya penulis dalam menampilkan pokok-pokok pemikiran dan ajaran Habib Ali al-Jufri dalam buku ini. Dr. Haidar Bagir

(Cendekiawan Muslim dan Direktur Mizan)

Di masa krisis moral, kehadiran buku yang ditulis oleh akhina fillah Dicky Ad Setiawan mengingatkan sebagian dari visi besar yang dibawa Baginda Habibillah Rasulullah Muhammad Saw: "menyempurnakan ahlaqul karimah". baik dalam muamalah (interaksi) bersama Allah Swt maupun dengan ciptaan-Nya. Semoga kita dianugerahi dan diberi taufiq agar dapat mengikuti dan meneladani Beliau amin amin amin Ya Rabbal 'alamin

Dr. H. Muhamad Musyafa', S.Pd.I., M.Th.I

(Ketua Pusat TQN Al- Ustmaniyah dan Kepala Ponpes Assalafi Al Fithrah Surabaya)

Santri masa kini memiliki tantangan yang cukup "berat" dalam upaya melestarikan tradisi intelektual (ilmiah) dan spiritual (amaliah) para salafush

shalih. Salah satu tantangan itu adalah bagaimana "mengemas" dan menyampaikan nilai-nilai ajaran Islam yang ramah, damai dan moderat, di tengah "gempuran" paham-paham esktremis dewasa ini. Saudara Dicky Adi

Setiawan, adalah salah satu santri milenial yang mampu menjawab tantangan itu, dengan hadirnya buku ini. la berhasil mengulas dengan baik, pemikiran tokoh yang sangat alim dan teduh, yaitu al- Habib Ali al-Jufri. Untuk itu, saya ucapkan selamat dan sukses Dr. Kusroni, S.Ud., M.Th.I

(Dosen Prodi IImu al-Qur'an dan Tafsir STAI Al Fithrah Surabaya)

Moderasi Beragama menjadi agenda semua umat beragama untuk melakukan rasionalisasi dan fungsionalisasi mereka dalam hidup bersama. Kajian moderasi beragama dari pemikiran keturunan Arab yang dikontekskan dengan kehidupan keagamaan di Indonesia menjadi fenomena menarik dan menjadi warna tersendiri dari buku ini.

Dr. Muhammad Murtadlo, M.A

(Peneliti Utama Kementrian Agama RI)

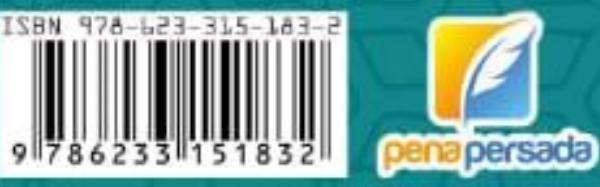

\section{Pengantar}

Prof. Dr. H Abdul Mustaqim, M.Ag.

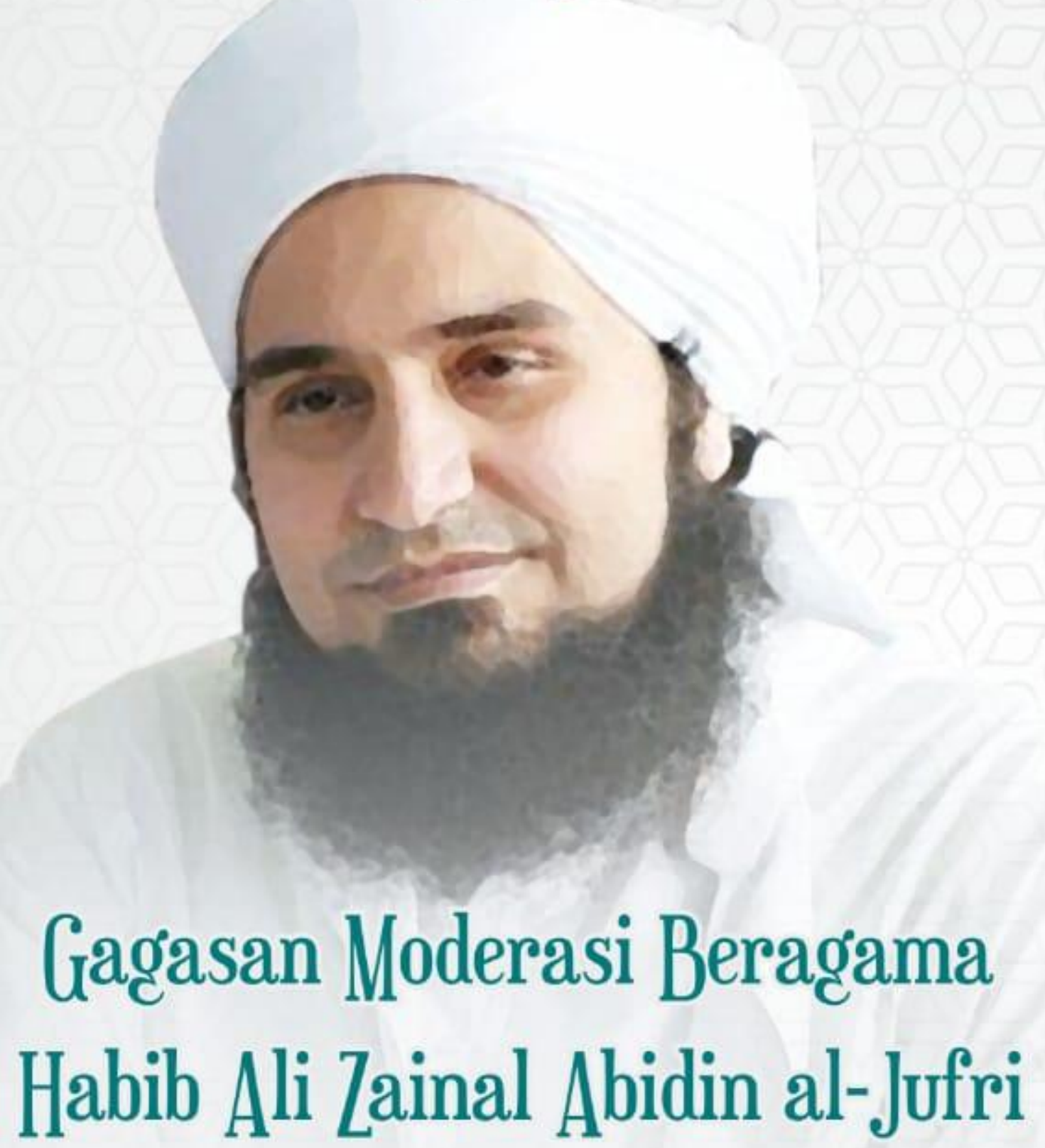

Saya memiliki kesesuaian pandangan dengan Habib Ali al-Jufri. Bukan saja beliau luas pandangannya tapi juga luwes sikapnya. Santun dalam berdakwah dan tajam dalam berargumen

Prof. Nadirsyah Hosen, Ph.D

(Rais Syuriah PCI Nahdlatul Ulama Australia-New Zealand)

Dicky Adi Setiawan 


\title{
GAGASAN MODERASI BERAGAMA HABIB ALI ZAINAL ABIDIN AL-JUFRI
}

\author{
Dicky Adi Setiawan
}

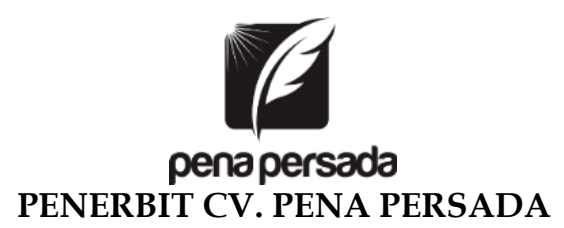




\title{
GAGASAN MODERASI BERAGAMA \\ HABIB ALI ZAINAL ABIDIN AL-JUFRI
}

\author{
Penulis:
}

Dicky Adi Setiawan

ISBN : 978-623-315-183-2

\author{
Editor \\ Nunu Ahmad An-Nahidl, M.S.i \\ Design Cover : \\ Retnani Nur Briliant \\ Layout : \\ Nisa Falahia \\ Penerbit CV. Pena Persada \\ Redaksi : \\ Jawa Tengah \\ Email : penerbit.penapersada@gmail.com \\ Website : penapersada.com Phone : (0281) 7771388 \\ Anggota IKAPI \\ All right reserved \\ Cetakan pertama : 2021
}

Jl. Gerilya No. 292 Purwokerto Selatan, Kab. Banyumas

Hak Cipta dilindungi oleh undang-undang. Dilarang memperbanyak karya tulis ini dalam bentuk apapun tanpa izin penerbit 


\section{PERSEMBAHAN}

Untuk almamater tercinta yang sangat saya harapkan ridha dan berkah dari pendiri, Pondok Pesantren al-Salafi al-Fithrah

Surabaya, STAI al-Fithrah Surabaya, dan kepada seluruh santri yang menuntut ilmu di bawah naungannya semoga diberi keberkahan, menjadi orang yang bermanfaat bagi dirinya, lingkungan serta umat manusia 


\section{APRESIASI}

Usai membaca buku ini meski tak menyeluruh, saya bergumam sendiri: "wow, keren, cerdas dan progresif". Lagi-lagi saya harus menyampaikan perasaan senang sekaligus bangga melihat santri pondok pesantren "salaf", yang mampu menghidangkan pikiran-pikirannya yang menghembuskan nafas cinta dan kemanusiaan dengan narasi yang damai.

Saya melihat penulis buku ini, Dicky Adi Setiawan, membaca cukup banyak referensi karya para ulama klasik terutama dalam perspektif sufisme. Tetapi yang menarik lagi dia juga mengapresiasi pandangan intelektual dan penulis non muslim. Ini yang saya ingin sampaikan kepada para santri. "Bentangkan dadamu untuk menerima pikiran-pikiran yang mencerdaskan, mencerahkan, dan bermanfaat bagi dunia kemanusiaan oleh siapapun dan dari manapun. Karena semua pengetahuan yang baik dan berguna untuk manusia patut diapresiasi dan diambil. Karena semua yang baik dan bermanfaat itu dari Allah.

Ibnu Rusyd, Filsuf muslim besar mengatakan dalam "fashl al-Maqal": Jika kita menemukan kebenaran dari mereka yang berbeda agama, kita patut menerima dan menghormatinya. Sebaliknya jika kita menemukan kesalahan, maka kita patut memperingatkan dan memaafkannya". Ia memandang, bahwa perbedaan agama tidak menjadi penghalang untuk membangun jembatan "hiwar khariji” (dialog antar umat beragama)

Tema "Moderasi Beragama", hari ini menjadi perbincangan publik luas menyusul berkembangnya gerakan ekstrimisme kekerasan dan intoleransi yang dilakukan oleh sebagian orang atas nama agama. Ia sedang menjadi trend besar bukan hanya di negeri ini tetapi juga di dunia. Para agamawan dituntut untuk memberikan jawaban atas realitas yang menentang dan mencemaskan ini. 
Melalui buku ini, Dicky mengurai terma dengan cukup baik dan luas sambil mendasarkan diri pada sumber-sumber keilmuwan Islam yang luas dan otentik. Sebagai seorang santri Dicky cukup berhasil menghidangkan Islam sebagai agama yang ramah, moderat dan menghargai hak-hak asasi semua orang, siapapun dia.

Hal menarik lainnya dalam buku ini adalah penulis menampilkan tokoh ulama kharismatik yang sangat terkenal dan menjadi tokoh idola di negeri ini Habib Ali Zainal Abidin al-Jufri . Pandangan-pandangan keagamaan ulama ini mencerminkan esensi dan visi profetik Islam. Yakni pandangan wasathi, moderat dan penuh etika kemanusiaan universal dan cinta. Penulis tampaknya begitu mengamumi tokoh ini. Saya merasa bahwa seluruh pandangan tokoh ini mencercap ke dalam pikirannya.

Saya berharap buku ini dapat dibaca oleh publik luas untuk pada gilirannya mereka tercerahkan lalu mengaktualisasikan cara pandang Islam wasathi atau moderat ini dalam kehidupan bersama.

\section{Dr. (HC) KH Husein Muhammad}

(Pendiri Fahmina Institute)

Saya memiliki kesesuaian pandangan dengan Habib Ali alJufri. Bukan saja beliau luas pandangannya tapi juga luwes sikapnya. Santun dalam berdakwah dan tajam dalam berargumen

Prof. Nadirsyah Hosen, Ph.D

(Rais Syuriah PCI Nahdlatul Ulama Australia-New Zealand)

Habib Ali al-Jufri bagi saya bukan cuma da'i, sehebat apa pun beliau. Beliau adalah seorang intelektual Muslim dan pemikir sufi kaliber dunia. Meski tak bisa dipungkiri bahwa beliau besar dan berakar kuat dalam lingkungan tradisi Thariqah 'Alawiyah, pemikiran beliau jauh melampui itu semua. Lebih lagi dalam hal sikap kemanusiaan, Habib Ali adalah teladan dan personifikasi sifat welas asih, toleransi dan moderasi ajaran agama Islam. Kita 
semua berterima kasih atas upaya penulis dalam menampilkan pokok-pokok pemikiran dan ajaran Habib Ali al-Jufri dalam buku ini

Dr. Haidar Bagir. (Cendekiawan Muslim dan Direktur Mizan)

Moderasi Beragama menjadi agenda semua umat beragama untuk melakukan rasionalisasi dan fungsionalisasi mereka dalam hidup bersama. Kajian moderasi beragama dari pemikiran keturunan Arab yang dikontekskan dengan kehidupan keagamaan di Indonesia menjadi fenomena menarik dan menjadi warna tersendiri dari buku ini.

Dr. Muhammad Murtadlo, M.A

(Peneliti Utama Kementrian Agama RI)

Di masa krisis moral, kehadiran buku yang ditulis oleh akhina fillah Dicky Adi Setiawan mengingatkan sebagian dari visi besar yang dibawa Baginda Habibillah Rasulullah Muhammad Saw: "menyempurnakan ahlaqul karimah", baik dalam muamalah (interaksi) bersama Allah Swt maupun dengan ciptaan-Nya. Semoga kita dianugerahi dan diberi taufiq agar dapat mengikuti dan meneladani Beliau amin amin amin Ya Rabbal 'alamin

Dr. H. Muhamad Musyafa', M.Th.I

(Ketua Pusat TQN Al- Ustmaniyah serta Kepala Ponpes Assalafi Al Fithrah Surabaya)

Semakin tinggi ilmu seseorang maka semakin luas cara pandangnya dan semakin dekat ia dengan Tuhannya semakin besar kasih sayangnya pada mahluk Tuhannya. Inilah yang saya lihat dari Sayyid al Habib Zainal Abidin Al Jufri. Sikapnya luwes menandakan kedalaman ilmunya dan benar saja, tulisan-tulisan serta ceramahnya yang bernas membuktikan hal tersebut

Dr. Iksan Kamil Sahri, M.Pd.I

( Ketua LPPM STAI Al Fithrah Surabaya) 
Santri masa kini memiliki tantangan yang cukup "berat" dalam upaya melestarikan tradisi intelektual (ilmiah) dan spiritual (amaliah) para salafush shalih. Salah satu tantangan itu adalah bagaimana "mengemas" dan menyampaikan nilai-nilai ajaran Islam yang ramah, damai dan moderat, di tengah "gempuran" paham-paham esktremis dewasa ini. Saudara Dicky Adi Setiawan, adalah salah satu santri milienal yang mampu menjawab tantangan itu, dengan hadirnya buku ini. Ia berhasil mengulas dengan baik, pemikiran tokoh yang sangat alim dan teduh, yaitu al- Habib Ali al-Jufri. Untuk itu, saya ucapkan selamat dan sukses

Dr. Kusroni, S.Ud., M.Th.I

(Dosen Prodi Ilmu al-Qur'an dan Tafsir STAI Al Fithrah Surabaya)

Umat Islam dewasa ini dihadapkan pada dua arus pemikiran yang saling berbenturan, ekstremisme dan liberalisme. Oleh karenanya pemikiran wasatiyah Islam harus dikembangkan dan dikampanyekan. Al Habib Ali al-Jufri adalah salah satu tokoh moderat yang dalam dakwahnya senantiasa mengampanyekan nilai-nilai wasatiyah Islam rahmatan lil alamin, jauh dari ekstremisme maupun liberalisme. Buku ini berusaha mengetengahkan pemikiran Habib Ali al-Jufri tentang gagasangagasan moderasi beragama berbasis pada turats dan pemikiran salaf. Buku ini sangat layak dibaca oleh umat Islam, khususnya para aktivis moderasi beragama agar wawasan keberagamaannya lebih segar dan moderat

\section{Muhammad Khudhori, M.Th.I}

(Dosen Fakultas Ushuluddin dan Humaniora UIN Walisongo semarang)

Moderasi beragama tidak hanya berhenti pada tataran konsep pengetahuan semata, ia menjadi landasan dalam bersikap dan berperilaku umat beragama dalam kehidupan bermasyarakat. Di tengah minimnya kajian literatur moderasi beragama, buku "Gagasan Moderasi Beragama Habib Ali Zainal Abidin al-Jufri" karya Dicky Adi Setiawan menjadi penting menjawab bagaimana konsepsi dan perilaku moderasi beragama dipraktekkan dalam 
kehidupan umat yang toleran dan damai. Buku ini layak dibaca sebagai salah satu referensi dalam kajian moderasi beragama.

Ta'rif A, Jalil

(Peneliti Puslitbang Pendidikan Agama dan Keagamaan RI) 


\section{Motto}

Sepandai-pandai seseorang jika tidak menulis akan hilang ditelan masa. Sebab itu, menulislah yang sekira bermanfaat bagi orang lain, walaupun sepatah kata. Karena dengan menulis engkau akan tetap hidup walau jasadmu sudah tiada

(Dicky Adi Setiawan) 


\section{PRAKATA PENULIS}

Alhamdulillah segala puji bagi Allah Swt yang penulis tak mampu memuji sebagaimana Engkau memuji Dzat-Mu. Berkat pertolongan dan kasih sayang-Mu, penulis dapat menyelesaikan buku yang berjudul "Gagasan Moderasi Beragama Habib Ali alJufri".

Buku yang berada di tangan anda saat ini merupakan hasil penelitian penulis yang mencoba mendeskripsikan pemikiran Habib Ali al-Jufri tentang moderasi beragama. Data yang digunakan penulis dalam mendeskripsikan pemikiran Habib Ali al-Jufri selain menelaah karya-karyanya juga menukil dari ceramah-ceramahnya yang ada di media sosial seperti youtoube dan semacamnya.

Adapun jika berbicara mengenai moderat, dalam pandangan sebagian kelompok ada yang mendefinisikan bahwa kata moderat ialah sesuatu yang berada di tengah di antara dua hal. Ada juga yang memaknai bahwa moderat itu ialah suatu tindakan yang tidak memihak ke kanan dan ke kiri. Jika meminjam istilah orang Arab bahwa sesuatu akan nampak mulia apabila di tengah-tengahnya diletakan perhiasan. Dan seperti ungkapan "kamu berada ditengah kaum" artinya kamu adalah orang yang mulia di antara meraka serta ungkapan "kamu berada ditengah mereka" artinya kamu mendaimaikan konflik diantara mereka. Jika berkaca pada Islam, sebenarnya kata moderatisme atau wasatiyyah sudah tidak asing lagi. Oleh sebab itu yang ada hanyalah meneguhkan moderat yang telah ada, karena Islam sendiri telah dijadikan Allah Swt sebagai agama yang moderat.

Menurut Habib Ali al-Jufri definisi-definisi di atas semuanya benar, akan tetapi hal tersebut merupakan sebagian saja dari arti moderat, sedangkan secara esensi ialah tindakan yang dapat menggabungkan antara akal dan hati dengan standar yang kemudian disepakati. Pendek kata, orang-orang yang moderat ialah orang-orang yang selalu bermuamalah hati dengan Allah Swt, dan dampak dari hati yang bermuamalah dengan Allah adalah tidak akan menggelorakan kebencian terhadap, keluarga, masyarakat, negara, umat dan alam jagad raya ini. 
Hal yang demikian dikarenakan rasa kemanusiaan selalu timbul di dalam hati mereka yang selalu bermuamalah hati dengan Allah Swt. Tegasnya, esensi moderatisme ialah kemanusiaan yang diutamakan dan didahulukan sebelum keberagamaan. Dalam konteks ke-Indonesiaan sebagaimana yang ketahui bahwa hadirnya Islam bukan untuk menghancurkan atau memerangi selain Islam agar masuk ke dalam Agama Islam. Namun, sebagai rahmat bagi alam semesta.

Faktanya, akhir-akhir ini banyak sebagian kelompok yang gagal faham memaknai ajaran Islam sehingga mereka menerjang batasan-batasan yang seharusnya tidak dilakukan. Hal tersebut membuat Islam diklaim oleh agama lain sebagai agama yang keras, intoleran dan rumor lain yang tak pantas disandingkanya. Habib Ali al-Jufri berpendapat bahwa hal semacam ini adalah potret dari keberagamaan seseorang yang salah. Tegasnya, keberagamaan itu berpusat di dalam hati, jika keberagamaan seseorang itu baik maka rasa kemanusiaanya pun akan menjadi baik. Dan penting kita ketahui bahwa umat yang moderat bukanlah yang pandai berpikir akan tetapi seberapa besar rasa (dzauq) yang dimilikinya.

Sehubungan dengan pembahasan ini, Habib Ali al-Jufri menawarkan sebuah konsep untuk menangkal Islam radikal, intoleran, ekstrem dan semacamnya. Konsep tersebut pokok intinya ialah memanusiakan manusia. Artinya, jika seseorang menjaga kemanusiaanya, ia bisa menjadi muslim yang lurus dan ikhlas dalam komitmennya, dan ketaatan pada makna dan realisasi kemanusiaan adalah gelar kejujuran serta kesetiaan kepada Allah Swt. Begitu juga sebaliknya, seberapapun bentuk komitmen seseorang, jika masih menyia-nyiakan makna kemanusiaan, maka ia akan semakin bengkok dalam keberagamaannya. Pendek kata, bahwa poin penting dalam menggelorakan Islam ialah mengemas nilai-nilai agama dengan kemanusiaan, yang demikian ini agar dapat merealisasikan perdamaian antar umat beragama.

Karena dalam kehidupan beragama tak lain ialah mengkontestasikan simbol-simbol keagamaan. Dalam kontestasi, 
akan muncul ragam interpretasi, dan penilaian terhadap pihak lain. Dari sinilah konflik dan harmoni menjadi keniscayaan. Lalu, teks-teks syar'i tidaklah patut dibilang tidak moderat, karena jika mengaca pada ajaran Islam sejak dulu hingga sekarang sudah teridentifikasi sebagai agama moderat. Bisa jadi lahirnya pemikiran radikal atau ekstrem berawal dari pola penafsiran dan pemahaman seseorang terhadap teks-teks syar'i yang salah. Sikap kekerasan dan pertingkaian yang dibuahkan ideologi radikal membuatnya hendak ditiadakan. Mungkin dari sekian alasan, isuisu terorisme, khilafah, dan semacamnya disebabkan rasa takut terhadap Islam dan menganggapnya sebagai agama yang keras dan intoleran.

Tidak disalahkan, wajah Islam dibilang beragam atau khazanah keislaman penuh dengan pendapat dan pemikiran yang berlainan. Meski rujukan utama Islam hanya berkisar pada alQur'an dan as-Sunnah, justru keberagaman pemikiran adalah sebuah kekayaan dan rahmat bagi umat Islam. Namun, jika fenomena demikian malah berujung pada perseteruan dan bercerai-berainya persatuan, inilah yang sangat dipermasalahkan. Hal ini dilatarbelakagi oleh pemikiran radikal dan bahkan ekstrem yang terus menghiasi zona pemikiran Islam. Pola pemikiran ini senantiasa memberikan konsekuensi yang berupa kekerasan, perseteruan serta saling merebut kekuasaan dan hak.

Walhasil, dalam buku ini, penulis berikhtiar menguraikan akar permasalahan dari isu-isu yang masih hangat di Indonesia dalam perspektif Habib Ali al-Jufri, yakni tentang adanya intoleran, kekerasan, saling menghujat, dan semacamnya. Hemat penulis, konsep yang ditekankan Habib Ali al-Jufri ialah terletak pada rasa ( $d z a u q)$ kemanusiaan, jika seseorang tidak mempunyai rasa kasih sayang atau bahkan hilang, maka hal itulah yang memicu terjadinya kekerasan, intoleran, dan semacamnya. Begitu juga sebaliknya, jika dalam diri tertanam rasa kemanusiaan yang mendalam yang mendahului keberagamaannya, maka damailah negeri ini. 
Selesainya penelitian dan penulisan buku ini tentu tidak lepas dari dorongan dan bantuan berbagai pihak. Untuk itu, dalam kesempatan ini penulis ingin mengucapkan banyak terima kasih kepada berbagai pihak yang telah berperan dan membantu proses penulisan dan penerbitan buku ini.

Pertama penulis mengucapkan terima kasih kepada Kepala Puslitbang Pendidikan Agama dan Keagamaan, Badan Litbang dan Diklat Kementerian Agama RI selaku promotor yang mendanai penelitian ini. Terima kasih juga kepada Dr. Moh. Murtadho, M.A selaku inspirator yang selalu memberikan motivasi dan arahan, juga kepada Ustadz Nunu Ahmad AnNahidl, M.S.i selaku pembimbing juga editor buku ini yang mengarahkan, menuntun dan mengeja per-kata hingga penulis dapat menyelesaikan penulisan ini. Terima kasih juga kepada Prof. Dr. H Abdul Mustaqim, M.Ag dan Dr. Haidar Bagir sebagai motivator serta guru penulis yang sangat penulis harapkan doa dan berkahnya.

Kepada kedua orang tua penulis, Abi Suwondo (alm.) Umi Ngatinah yang selalu mendoakan dan memberikan dorongan kepada penulis demi kesuksesan studi. Tak lupa kepada adikadikku tersayang serta keluargaku, saya mengucapkan banyak terima kasih yang tak terhingga.

Kepada Guru rohani penulis; Hadratusyaikh Ahmad Asrari al-Ishaqi yang telah membimbing dan menuntun penulis dalam perjalanan kehadirat-Nya, juga kepada Kepala Pondok Assalafi alFithrah Surabaya Ust. Dr. Muhamad Musyafa', S.Pd.I, M.Th.I, kepada Ust. Dr Kusroni, M.Th.I selaku Sekprodi IAT STAI AlFithrah Surabaya yang selalu memotivasi dan mewasiatkan agar santri itu harus berkarya, kepada Ust. Fathur Rozi, M.H.I selaku mudir 'aam Ma'had Aly Al Fithrah Surabaya dan segenap dosen serta guru-guru penulis tak dapat kami sebutkan satu persatu penulis ucapkan jazakumullah khairan katsiran.

Kepada sahabat dan teman-teman diskusi penulis serta kepada penerbit CV Pena Persada yang telah berkenan menerbitkan hasil penelitian ini penulis sampaikan banyak terima kasih. Akhir kata, kepada mereka semua penulis hanya bisa 
berdoa semoga jasa dan kebaikan mereka mendapat balasan terbaik dari Allah Swt.

Kendal, 8 Januari 2021

Dicky Adi Setiawan 


\section{KATA PENGANTAR \\ Moderasi Beragama Sebagai Basis Membangun Kohesi Sosial \\ Oleh: Prof. Dr. H. Abdul Mustaqim, M.A \\ Guru Besar Ilmu al-Qur'an dan Tafsir UIN Sunan Kalijaga \\ Yogyakarta dan Pengasuh Pesantren Mahasiswa LSQ \\ Ar-Rohmah Yogyakarta.}

Diversity is reality, but harmony is necessity

No peace among the nations without peace among the religions.

No peace among the religions without dialogue between the religions.

No dialogue between the religions without investigating the foundation of the religions. ${ }^{1}$

Keragaman adalah sebuah realitas, tetapi keharmonisan adalah sebuah keharusan. Tidak ada perdamaian bangsabangsa, tanpa peradamaian diantara agama-agama. Tidak ada perdamaian agama-agama, tanpa ada dialog antara agama-agama. Tidak ada dialog antara agama-agama, tanpa keberanian untuk meneliti tentang fondasi dasar agamaagama tersebut.

Karakter dasar Islam adalah moderasi the nature of Islam is moderation). Maka, mengartikulasikan Islam yang menyimpang dari nilai-nilai moderasi dapat dinilai sebagai sebuah kegagalan memahami ajaran Islam. Itu sebabnya, mengacu pada kutipan di atas, penulis menambahkah bahwa fondasi dasar beragama adalah moderasi (wasthiyah). Jika fondasi ini lemah, maka akan bisa meruntuhkan otentisitas keberagamaan kita.

Namun, tentu menjadi keprihatinan kita bersama, bahwa akhir-akhir fenomena radikalisasi agama dan intoleransi, baik yang bersifat wacana maupun aksi merupakan fakta sosial yang tak terbantahkan. ${ }^{2}$ Dalam studi Ashour, proses radikalisasi umumnya berlangsung dari tahap intoleransi, radikalisasi

${ }^{1}$ Dikutip oleh Prof. Dr. Nurcholis Madjid, Pengantar, dalam Georfe B. Grose dan Benjamin J. Hubbard (ed), Tiga Agama Satu Tuhan, Sebuah Dialog, Cet. 2 (Jakarta: Paramadina, 1998), hlm. xviii

${ }^{2}$ Lihat Alamsyah M Dja'far Libasut Taqwa Siti Kholishoh, Intoleransi dan Radikalisme di Kalangan Perempuan (Jakarta Publikasi Wahid Foundation 2017) 
ideologi, dan kemudian radikalisasi perilaku (Ashour, 2009: 5). Harus dicatat di sini bahwa radikalisme bukanlah gejala khas Islam. Ia terjadi pada agama dan kepercayaan lain, dan untuk tujuan yang beragam, dari politik hingga ekonomi. Misalnya saja radikalisme di sebagian kalangan dalam agama Buddha di Myanmar atas isu etnis Rohingya. Dengan kata lain, soft radicalism dapat berkembang menjadi hard radicalism.

Konflik yang mengatasnamakan agama tampak semakin menggurita, yang berimbas pada tindakan kekerasan dan tentu saja ini sangat menciderai, bukan saja pada nilai dasar keberagamaan itu sendiri yang mendorong untuk hidup rukun, tetapi juga nilai kemanusiaan yang menuntut untuk saling mencintai. Agama itu sebenarya hadir ke dunia, bukan untuk kepentingan Tuhan, melainkan untuk kepentingan manusia, yakni agar tercapai kehidupan yang maslahah, baik di dunia maupun di akhirat. Hal itu antara lain diisyaratkan pada penamaaan akhir surat dalam al-Qur'an sebagai Surat al-Nas (Surat Manusia). Di samping itu, ada sekian banyak ayat dalam al-Qur'an yang diawali menyapa dengan panggilan yâ ayyuha al-nâs (wahai manusia). Tidak berlebihan jika Prof. Dr. Fazlur Rahman dalam bukunya Major Themes of the Qur'an menyebut bahwa al-Qur'an sesungguhnya merupakan "respon Tuhan" buat manusia, sebagai wujud sifat Rahman-Rahim-Nya. Itu diperkuat dengan deklarasi Tuhan sendiri di awal surat al-Fatihah, Bimillah Rahman al-Rahim. Seolah Tuhan hendak mengabarkan, wahai manusia tebarkan sifat kasih sayang kepada semua makhluk-Ku, karena Aku adalah Tuhan yang Pengasih dan Penyayang.

Untuk mengembalikan sikap moderasi beragama dalam konteks masyarakat yang multi agama dan multi kultur menjadi sebuah keniscyaan. Sebab hanya dengan sikap moderasi beragam, kita akan mampu membangun kohesi sosial, demi menggapai kemaslahatn bersama. Tidak mungkin tercapai kemaslahatan, manakala dalam kehidupan beragama isinya hanya konflik dan kekerasan. Memang, ketegangan dan konflik dalam kehidupan beragama, sering kali tidak dapat dihindari, karena berbagai faktor, baik sosial, kultur, ekonomi, politik maupun teologi. 
Namun, satu hal yang penting untuk ditegaskan adalah bagaimana konstruksi keberagamaan kita ini, mencerminkan paradigma keberagamaan moderasi, sehingga tidak mudah tersulut konflik. Maka, hemat penulis bahwa paradigma yang cocok untuk resolusi konflik adalah paradigma moderasi beragama: dari model keberagamaan konflik menuju perdamaian (min al-ikhtilâf ilâ al-i tilâf), dari kebencian menuju cinta kasih (minal ‘adâwah ilâ al-mahabbah), dari perpecahan menuju persatuan (min furqah ila al-wihdah), dari radikalisme menuju moderasi (min alradikaliyyah ila al wasthiyah).

\section{Apa itu Moderasi Beragama?}

Pertanyaannya kemudian adalah apa sesungguhnya yang dimaksud moderasi beragama (wasathiyah al-tadayyun) ? Mengapa sikap wasathiyah sangat penting dalam konteks beragama? Penulis perlu menegaskan kembali bahwa karakter dasar Islam adalah wasathiyah (moderasi), secara bahasa berarti sikap yang tengahtengah, tidak terlalu ekstrem ke kanan atau ke kiri, serta tidak berlebih-lebihan (al-ghuluww) dalam menerapkan ajaran agama. Segala bentuk sikap yang ekstrem dapat dinilai sebagai keluar dari karakter dasar Islam. Itu sebabnya, al-Qur'an mengkritik sikap esktrem terhadap Ahli Kitab (Yahudi dan Nasrani). "Wahai Ahli Kitab janganlah kalian bersikap ghuluw (ekstrem) dalam agama kalian..." [Q.S. al-Nisâ' [4]:171]. Al-Qur'an juga menyatakan bahwa umat Islam adalah ummatan wasathan, (QS. al-Baqarah [2]:143), yakni umat yang memiliki sikap moderat, umat terbaik, sehingga ajarannya akan menjadi teladan bagi banyak orang.

Terkait dengan sikap wasathiyah ini yang menarik adalah bahwa letak ayat ini persis di tengah-tengah Surat al-Baqarah, yang jumlah keseluruhan ayatnya adalah 286. Inilah yang dalam bahasa Dr. Rasyad Khalifah disebut sebagai i'jâz 'adadî (mukjizat bilangan). Di sisi lain, ternyata konteks ayat tersebut berbicara tentang perpindahan arah Kiblat, dari Baitul Maqdis di Palestina ke Ka'bah Baitullah di Masjidil Haram Makkah. Menurut para ahli, posisi Ka'bah secara geografis juga persis di tengah-tengah planet bumi. Hal ini semakin meneguhkan keyakinan penulis bahwa sikap moderasi (wasathiyah) adalah sikap yang ideal dan terbaik, 
khususnya dalam konteks kehidupan beragama, baik kita sebagai makhluk individual maupun makhluk sosial. Sikap moderasi mengantarkan seseorang dapat lebih fleksibel dalam mengatasi konflik-konflik batin yang ada dalam dirinya sendiri, dan memudahkan seseorang dalam berinteraksi dengan the others (komunitas umat beragama yang berbeda).

Hemat penulis, setidaknya, terdapat lima ayat al-Qur'an yang secara tegas merujuk pada term w-s-th (wasathiyah, moderasi). Semuanya menunjukkan kesan makna yang positif, yaitu: Pertama, terkait tentang posisi umat Islam sebagai umat moderat (Q.S. al-Baqarah [2]:143) umat yang akan menjadi teladan dan saksi bagi umat-umat lain nanti di akhirat. Kedua, pentingnya menjaga shalat yang 'tengah-tengah' (al-shalâh al-wusthâ) (Q.S alBaqarah [2]: 238), Ketiga, perintah membayar kaffarah, ketika seseorang melanggar sumpah, yaitu memberikan makanan kepada sepuluh fakir miskin, dengan makanan 'terbaik', yaitu makanan yang biasa dimakan oleh keluarganya (Q.S.al-Ma'idah[5]:89). Keempat, apresiasi tentang orang yang paling baik pikirannya. "Berkatalah seorang yang paling baik pikirannya di antara mereka: "Bukankah aku telah mengatakan kepadamu, hendaklah kamu bertasbih (kepada Tuhanmu)? (Q.S.al-Qalam [68]: 28). Kelima, posisi kuda yang dengan gagah berani ketika berperang menyerbu ditengahtengah musuh (Q.S al-`Adiyât [100]: 5), karena dengan begitu kuda depat memporak-porandakan musuh.

Sementara itu, al-Qur'an juga menyebutkan secara tersirat, tentang baiknya sikap moderasi (tengah-tengah). Misalnya, perintah Allah Swt kepada Bani Israil agar menyembelih sapi betina yang usianya tengah-tengah, tidak terlalu muda tidak terlalu tua (Q.S. al-Baqarah [2]: 68). Kondisi umur para penduduk surga yang usianya tengah-tengah, tidak terlalu tua tapi juga tidak terlalu muda. Nabi Saw menjelaskan bahwa usia mereka sekitar tiga puluhan tahun, dan bidadari di surga yang disediakan untuk golongan kanan (ash-hâhbul yamîn), kelak umur mereka juga masih muda-muda (Q.S. al-Wâqi'ah [56]: 35-36). Moderasi juga ditunjukkan oleh sikap para Ash-hâabul Kahfi ketika keluar dari gua, hendak mencari makanan, mereka bersikap moderat. Al-Qur'an 
memerintahkan bersikap "wal yatalaththaf" (lemah lembut) kepada mereka ketika harus menemui para penduduk (Q.S.al-Kahfi [18: 19). Demikian pula, terkait dengan sikap seorang suami yang harus moderat ketika memperlakukan perempuan ketika sedang menstruasi (Q.S. al-Baqarah [2]: 222). Artinya, perempuan saat menstruasi tidak boleh diasingkan, sehingga tidak diizinkan tidur atau makan-minum bersama suami. Sebaliknya, mereka tetap saja boleh diajak bergaul sebagaimana biasanya, yang penting jangan sampai melakukan jima' (hubungan seksual) saat ia menstruasi.

\section{Mengapa Moderasi Beragama Penting?}

Lalu apa pentingnya sikap wasathiyah (moderasi)? AlQur'an menyatakan, yaitu litakûnû syuhadâ 'ala al-nâs wa yakûna al-rasûl ‘alaikum syahîdâ... (Q.S.al-Baqarah [2]:143). Yaitu, agar kalian umat Islam dapat menjadi saksi buat orang lain, bahwa kalian itu adalah sebaik-baik baik umat (khaira ummah) dan Rasulullah Saw kelak juga akan menjadi saksi buat kalian, bahwa kalian benar-benar committed dengan sikap moderasi tersebut. Hal itu karena, sikap moderasi adalah sikap yang ideal (al-mauqif almitsâli), sikap tengah-tengah antara ekstrem kanan dan ekstrem kiri, sikap yang meniscayakan elastisitas (al-murûnah), tidak terlalu keras, tetapi juga tidak terlalu lembek. Bukankah sesuatu yang elastis justru lebih bisa bertahan dan tidak mudah patah? Sikap lentur dan tidak kaku inilah yang menyebabkan Islam dapat bertahan dan selalu cocok (compatible) sepanjang zaman (shâlih likulli zamân wa makân). Islam selalu dapat menerima perubahan dan perkembangan zaman, sebab perubahan dan perkembangan bagian dari keniscayaan sejarah dan sunnah kehidupan.Pendek kata, sejauh sejalan dengan prinsip dasar nilai tauhid (ilâhiyah), nilai-nilai kemanusiaan (insâniyah) dan nilai kemaslahatan jauh dari mafsadah (maqâshidiyah), maka perubahan itu dapat diterima Islam.

\section{Apa saja Aspek-Aspek Moderasi Beragama?}

Pertanyaannya kemudian, pada dimensi apa saja Islam meletakkan nilai-nilai moderasi (wasathiyah)? Setidaknya ada beberapa point penting yang dielaborasi dalam hal ini, yaitu: 